\title{
Agromyces terreus sp. nov., isolated from soil
}

Correspondence
Jung-Hoon Yoon
jhyoon@kribb.re.kr

\section{Jung-Hoon Yoon, ${ }^{1}$ Peter Schumann, ${ }^{2}$ So-Jung Kang, ${ }^{1}$ Sooyeon Park ${ }^{1}$ and Tae-Kwang $\mathrm{Oh}^{1}$}

\author{
${ }^{1}$ Korea Research Institute of Bioscience and Biotechnology (KRIBB), PO Box 115, Yusong, \\ Taejon, Republic of Korea \\ ${ }^{2}$ DSMZ - Deutsche Sammlung von Mikroorganismen und Zellkulturen GmbH, Inhoffenstrasse 7b, \\ D-38124 Braunschweig, Germany
}

\begin{abstract}
A Gram-positive, non-motile, cream-coloured, curved or straight rod-shaped bacterial strain, DS-10 $0^{\top}$, was isolated from soil of Dokdo, Korea, and its taxonomic position was investigated by using a polyphasic approach. Strain $\mathrm{DS}-10^{\top}$ grew optimally at $25{ }^{\circ} \mathrm{C}$ and $\mathrm{pH} 7.0-8.0$ in the presence of $0.5-1.0 \%(\mathrm{w} / \mathrm{v}) \mathrm{NaCl}$. Strain $\mathrm{DS}-10^{\top}$ had peptidoglycan type B2 $\gamma$ [D-Glu-D-Dab (diaminobutyric acid)] and galactose and ribose as whole-cell sugars. Strain DS-10 ${ }^{\top}$ contained MK-11, MK-12 and MK-10 as predominant menaquinones. Major cellular fatty acids ( $>10 \%$ of total) were anteiso- $C_{15: 0}$, anteiso- $C_{17: 0}$, iso- $C_{16: 0}$ and iso- $C_{15: 0}$. Major polar lipids were diphosphatidylglycerol, phosphatidylglycerol and an unidentified glycolipid. The DNA G +C content was $71.1 \mathrm{~mol} \%$. Phylogenetic analysis based on 16S rRNA gene sequences showed that strain DS-10 $10^{\top}$ belonged to the genus Agromyces. Similarity values between the $16 \mathrm{~S}$ rRNA gene sequence of strain DS $-10^{\top}$ and those of the type strains of recognized Agromyces species ranged from 95.8 to $99.3 \%$. DNA-DNA relatedness data and differential phenotypic properties, together with the phylogenetic distinctiveness, demonstrated that strain DS-10 ${ }^{\top}$ could be differentiated from recognized Agromyces species. On the basis of the data presented, strain DS$10^{\top}$ is considered to represent a novel species of the genus Agromyces, for which the name Agromyces terreus sp. nov. is proposed. The type strain is DS $-10^{\top}\left(=\mathrm{KCTC} 19216^{\top}=\mathrm{JCM}\right.$ $\left.14581^{\top}\right)$.
\end{abstract}

The genus Agromyces was proposed by Gledhill \& Casida (1969) and, at the time of writing, comprises 18 species with validly published names: Agromyces ramosus (Gledhill \& Casida, 1969), A. cerinus (Zgurskaya et al., 1992), A. mediolanus (Suzuki et al., 1996), A. luteolus, A. rhizospherae and A. bracchium (Takeuchi \& Hatano, 2001), A. albus (Dorofeeva et al., 2003), A. aurantiacus (Li et al., 2003), A. fucosus and A. hippuratus (Zgurskaya et al., 1992; OrtizMartinez et al., 2004), A. ulmi (Rivas et al., 2004), A. neolithicus and $A$. salentinus (Jurado et al., 2005a), A. humatus, A. italicus and A. lapidis (Jurado et al., 2005b), A. subbeticus (Jurado et al., 2005c) and A. allii (Jung et al., 2007). Here we report on the taxonomic characterization of an Agromyces-like bacterial strain, DS-10 ${ }^{\mathrm{T}}$, which was isolated from soil of Dokdo, an island of Korea.

\section{Abbreviation: Dab, diaminobutyric acid.}

The GenBank/EMBL/DDBJ accession number for the $16 \mathrm{~S}$ rRNA gene sequence of strain DS-10 $10^{\top}$ is EF363711.

A table detailing the cellular fatty acid compositions of Agromyces terreus sp. nov. DS $-10^{\top}$ and the type strains of phylogenetically related Agromyces species is available as supplementary material with the online version of this paper.
Strain DS- $10^{\mathrm{T}}$ was isolated by using the standard dilution plating technique at $30{ }^{\circ} \mathrm{C}$ on 10 -fold-diluted nutrient agar (NA; Difco). The type strains of four recognized Agromyces species were used as reference strains for DNA-DNA hybridization experiments: A. salentinus DSM $16198^{\mathrm{T}}, A$. italicus DSM $16388^{\mathrm{T}}$ and A. lapidis DSM $16390^{\mathrm{T}}$ were obtained from the DSMZ and A. allii UMS-62 ${ }^{\mathrm{T}}$ was described by Jung et al. (2007). The morphological, physiological and biochemical characteristics of strain DS- $10^{\mathrm{T}}$ were investigated by using routine cultivation on trypticase soy agar (TSA; Difco) at $25{ }^{\circ} \mathrm{C}$. Cell morphology was examined by light microscopy (Nikon E600) and transmission electron microscopy. The presence of flagella was determined by using a Philips CM-20 transmission electron microscope with cells from exponentially growing cultures: for this purpose, cells were negatively stained with $1 \%(\mathrm{w} / \mathrm{v})$ phosphotungstic acid and the grids were examined after being air-dried. The Gram reaction was determined by using the bioMérieux Gram stain kit according to the manufacturer's instructions. Growth at various temperatures $\left(4-40{ }^{\circ} \mathrm{C}\right)$ was measured on TSA. Growth in the absence of $\mathrm{NaCl}$ and at various $\mathrm{NaCl}$ concentrations ( 0.5 and $1.0-10.0 \%, w / v$, at intervals of $1.0 \%$ ) was investigated in trypticase soy broth prepared 
according to the formula of the Difco medium. The $\mathrm{pH}$ range for growth was determined in nutrient broth (Difco) that was adjusted prior to sterilization to various $\mathrm{pH}$ values ( $\mathrm{pH} 4.5-10.5$ at intervals of $0.5 \mathrm{pH}$ units) by the addition of $\mathrm{HCl}$ or $\mathrm{Na}_{2} \mathrm{CO}_{3}$. Growth under anaerobic conditions was determined after incubation in an anaerobic chamber on TSA and on TSA supplemented with nitrate, both of which had been prepared anaerobically under nitrogen. Catalase and oxidase activities and hydrolysis of casein, gelatin, hypoxanthine, starch, Tweens 20, 40, 60 and 80, tyrosine, urea and xanthine were determined as described by Cowan \& Steel (1965). Aesculin hydrolysis and nitrate reduction were studied as described by Lányí (1987). Susceptibility to antibiotics was tested on TSA plates by using discs containing the following antibiotics: polymyxin B (100 U), streptomycin $(50 \mu \mathrm{g})$, penicillin $\mathrm{G}(20 \mathrm{U})$, chloramphenicol $(100 \mu \mathrm{g})$, ampicillin $(10 \mu \mathrm{g})$, cephalothin $(30 \mu \mathrm{g})$, gentamicin $(30 \mu \mathrm{g})$, novobiocin $(5 \mu \mathrm{g})$, tetracycline $(30 \mu \mathrm{g})$, kanamycin $(30 \mu \mathrm{g})$, lincomycin $(15 \mu \mathrm{g})$, oleandomycin $(15 \mu \mathrm{g})$, neomycin $(30 \mu \mathrm{g})$ or carbenicillin $(100 \mu \mathrm{g})$. Assimilation of various substrates, acid production from various substrates, enzyme activities and other physiological and biochemical properties were tested by using the API 20E, API 20NE, API 50CH and API ZYM systems (bioMérieux). Assimilation of various substrates was determined by inoculating API $50 \mathrm{CH}$ strips with cell suspension in AUX medium (bioMérieux). Acid production by fermentation was determined by using API $50 \mathrm{CHB}$ medium according to the manufacturer's instructions.

Cell biomass for DNA extraction and for analyses of cellwall components, isoprenoid quinones and polar lipids was obtained from cultures grown by shaking at 150 r.p.m. in trypticase soy broth (Difco) for 3 days at $25{ }^{\circ} \mathrm{C}$. Chromosomal DNA was isolated and purified according to the method described by Yoon et al. (1996), with the exception that RNase T1 was used in combination with RNase A to minimize contamination with RNA. The $16 \mathrm{~S}$ rRNA gene was amplified by PCR by using two universal primers as described previously (Yoon et al., 1998). Sequencing of the amplified 16S rRNA gene and phylogenetic analysis were performed as described by Yoon et al. (2003). The DNA G + C content was determined by the method of Tamaoka \& Komagata (1984) with a modification that DNA was hydrolysed and the resultant nucleotides were analysed by reversed-phase HPLC. DNA-DNA hybridization was performed fluorometrically according to the method of Ezaki et al. (1989) by using photobiotinlabelled DNA probes and microdilution wells. Hybridization was performed with five replications for each sample. The highest and lowest values obtained in each sample were excluded, and the means of the remaining three values were quoted as DNA-DNA relatedness values. Preparation of cell walls and determination of peptidoglycan structure were carried out by using the methods of Schleifer \& Kandler (1972), MacKenzie (1987) and Groth et al. (1996). Whole-cell sugars were determined as described by Komagata \& Suzuki (1987). Isoprenoid quinones were extracted according to the method of Komagata \& Suzuki (1987) and were analysed by using reversed-phase HPLC and a YMC ODS-A $(250 \times 4.6 \mathrm{~mm})$ column. Polar lipids were extracted according to the procedures described by Minnikin et al. (1984) and were identified by two-dimensional TLC followed by spraying with appropriate detection reagents (Minnikin et al., 1984; Komagata \& Suzuki, 1987). For fatty acid methyl ester analysis, cell mass of strain DS- $10^{\mathrm{T}}$ was harvested from TSA plates after incubation for 3 days at $25{ }^{\circ} \mathrm{C}$. The fatty acid methyl esters were extracted and prepared according to the standard protocol of the MIDI/Hewlett Packard Microbial Identification System (Sasser, 1990).

The morphological, cultural, physiological and biochemical characteristics of strain DS-10 ${ }^{T}$ are given in the species description below or are shown in Table 1. The almostcomplete 16S rRNA gene sequence of strain DS- $10^{\mathrm{T}}$ determined in this study comprised $1449 \mathrm{nt}$ (approximately $96 \%$ of the Escherichia coli 16S rRNA gene sequence). $16 \mathrm{~S}$ rRNA gene sequence analyses showed that strain DS $-10^{\mathrm{T}}$ was phylogenetically related most closely to members of the genus Agromyces (Fig. 1). In the neighbour-joining tree based on $16 \mathrm{~S}$ rRNA gene sequences, strain DS- $10^{\mathrm{T}}$ fell within the cluster comprising Agromyces species, particularly by forming a coherent cluster with $A$. allii, A. salentinus, A. italicus and A. lapidis (Fig. 1). Strain DS- $10^{\mathrm{T}}$ exhibited 16S rRNA gene sequence similarity values of 95.8 (A. bracchium) to $99.3 \%$ (A. salentinus) with respect to the type strains of recognized Agromyces species.

Chemotaxonomic data confirmed the phylogenetic affiliation of strain DS- $10^{\mathrm{T}}$ as a member of the genus Agromyces. The total hydrolysate of the peptidoglycan $(4 \mathrm{M} \mathrm{HCl}, 16 \mathrm{~h}$ at $100{ }^{\circ} \mathrm{C}$ ) of strain DS- $10^{\mathrm{T}}$ contained the amino acids diaminobutyric acid (Dab), alanine, glycine and glutamic acid in an approximate ratio of $1.0: 0.8: 1.0: 1.4$. The peptide Gly-D-Glu was detected by two-dimensional TLC after hydrolysis under milder conditions $(4 \mathrm{M} \mathrm{HCl}, 45 \mathrm{~min}$ at $100{ }^{\circ} \mathrm{C}$ ). Dinitrophenylation of the peptidoglycan revealed that Dab was the only $\mathrm{N}$-terminal amino acid in the interpeptide bridge. From these data, it was concluded that strain DS- $10^{\mathrm{T}}$ had peptidoglycan type B2 $\gamma$, D-Glu-DDab, as described by Schleifer \& Kandler (1972). The amino acids in positions 1 and 3 were glycine and L-Dab, respectively. Cell-wall sugars were galactose and ribose. Strain DS- $10^{\mathrm{T}}$ contained MK-11, MK- 12 and MK-10 at peak area ratios of approximately 49,31 and $16 \%$, respectively, as the predominant menaquinones. Strain DS- $10^{\mathrm{T}}$ contained large amounts of branched-chain fatty acids; the major components ( $>10 \%$ of total fatty acids) were anteiso- $\mathrm{C}_{15: 0}(40.5 \%)$, anteiso- $\mathrm{C}_{17: 0}(20.5 \%)$, iso$\mathrm{C}_{16: 0}(19.4 \%)$ and iso- $\mathrm{C}_{15: 0}(11.8 \%)$ (see Supplementary Table S1 in IJSEM Online). This fatty acid profile was similar to those of recognized Agromyces species (Takeuchi \& Hatano, 2001; Li et al., 2003; Jurado et al., 2005a, b, c; Jung et al., 2007). Major polar lipids detected in strain 
Table 1. Differential phenotypic characteristics between strain $\mathrm{DS}-10^{\top}$ and phylogenetically related Agromyces species

Taxa: 1, strain DS- $10^{\mathrm{T}}$; 2, A. allii (data from Jung et al., 2007); 3, A. salentinus (Jurado et al., 2005a); 4, A. italicus (Jurado et al., 2005b); 5, A. lapidis (Jurado et al., 2005b). +, Positive; -, negative; v, variable (data in parentheses are for the type strain); w, weakly positive; ND, not determined or not described. All are positive for catalase, hydrolysis of aesculin, acid production from glycerol, D-arabinose, arbutin, L-fucose, glycogen and starch (not determined for A. allii), cellobiose, galactose, D-glucose, maltose and mannose, $\beta$-glucosidase and susceptibility to ampicillin, novobiocin (not determined for A. salentinus) and penicillin G. All are negative for indole production, acid production from mannitol, melibiose (not determined for $A$. allii), utilization of citrate, lipase (C14) and $\alpha$-mannosidase.

\begin{tabular}{|c|c|c|c|c|c|}
\hline Characteristic & 1 & 2 & 3 & 4 & 5 \\
\hline Maximum temperature for growth $\left({ }^{\circ} \mathrm{C}\right)$ & 35 & 33 & 37 & 37 & 37 \\
\hline Growth at $10{ }^{\circ} \mathrm{C}$ & + & + & + & $\mathrm{w}$ & $\mathrm{w}$ \\
\hline Growth at $4.0 \%(\mathrm{w} / \mathrm{v}) \mathrm{NaCl}$ & + & - & + & + & + \\
\hline Nitrate reduction & + & + & - & + & + \\
\hline Oxidase activity & + & + & $\mathrm{V}$ & + & $\mathrm{V}$ \\
\hline \multicolumn{6}{|l|}{ Hydrolysis of: } \\
\hline Casein & - & + & + & + & + \\
\hline Gelatin & + & + & - & + & $\mathrm{V}$ \\
\hline Hypoxanthine & + & - & - & + & - \\
\hline Starch & + & - & + & + & + \\
\hline Tyrosine & + & - & + & + & + \\
\hline Tween 80 & + & - & - & - & - \\
\hline Xanthine & - & - & - & + & - \\
\hline Urea & - & - & + & - & - \\
\hline $\mathrm{H}_{2} \mathrm{~S}$ production & - & - & + & + & + \\
\hline \multicolumn{6}{|l|}{ Acid production from: } \\
\hline L-Arabinose & + & + & + & + & - \\
\hline Fructose & + & $\mathrm{v}(+)$ & + & + & + \\
\hline Gentiobiose & - & $\mathrm{ND}$ & $\mathrm{w}$ & - & - \\
\hline Lactose & - & + & - & $\mathrm{w}$ & - \\
\hline Raffinose & $\mathrm{w}$ & - & $\mathrm{w}$ & - & $\mathrm{W}$ \\
\hline Rhamnose & + & + & + & - & - \\
\hline Ribose & - & + & + & - & - \\
\hline Salicin & $\mathrm{w}$ & + & + & + & + \\
\hline Sucrose & + & + & + & - & + \\
\hline Trehalose & - & + & + & - & - \\
\hline Turanose & - & ND & + & - & - \\
\hline D-Xylose & + & + & + & + & - \\
\hline$N$-Acetylglucosamine & - & ND & - & - & + \\
\hline Amygdalin & - & $\mathrm{ND}$ & + & $\mathrm{w}$ & + \\
\hline Inulin & + & $\mathrm{ND}$ & + & - & + \\
\hline Utilization of malate & - & + & - & - & - \\
\hline \multicolumn{6}{|l|}{ Enzyme activity (API ZYM) } \\
\hline Alkaline phosphatase & - & - & + & + & + \\
\hline Valine arylamidase & - & + & ND & + & + \\
\hline Cystine arylamidase & - & + & ND & + & + \\
\hline$\alpha$-Chymotrypsin & - & $\mathrm{v}(+)$ & - & - & + \\
\hline$\alpha$-Galactosidase & - & - & - & - & - \\
\hline$\beta$-Galactosidase & $\mathrm{w}$ & + & + & + & + \\
\hline$\beta$-Glucuronidase & - & + & - & - & - \\
\hline \multicolumn{6}{|l|}{ Antibiotic susceptibility } \\
\hline Kanamycin & $\mathrm{w}$ & + & + & - & - \\
\hline Polymyxin B & $\mathrm{w}$ & + & + & - & - \\
\hline Streptomycin & + & + & + & - & - \\
\hline DNA G $+\mathrm{C}$ content $(\mathrm{mol} \%)$ & 71.1 & $71.1-71.3$ & 72.3 & 70.8 & 70.4 \\
\hline
\end{tabular}




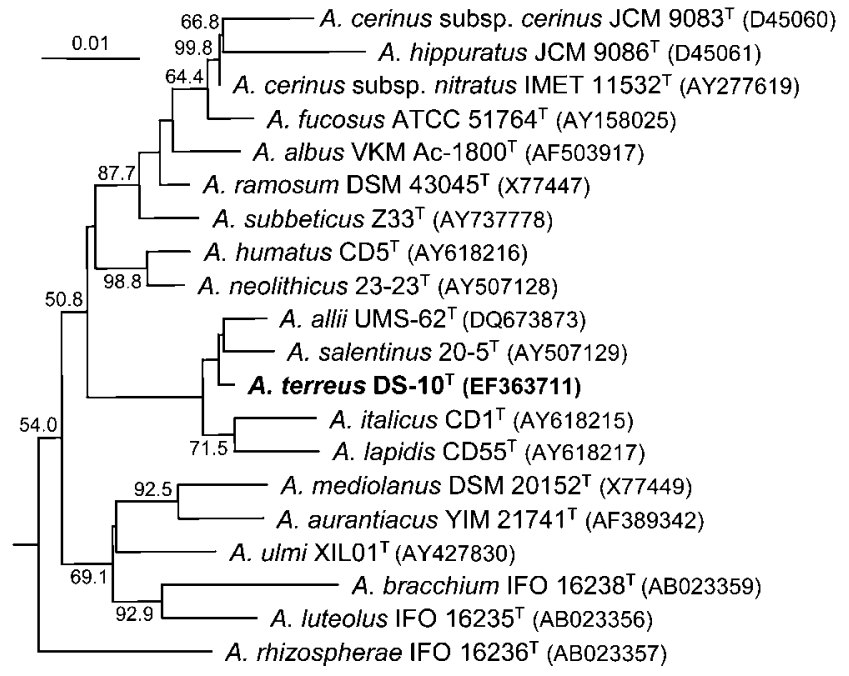

Fig. 1. Neighbour-joining tree showing the phylogenetic positions of strain DS-10 $10^{\top}$ and Agromyces species based on 16S rRNA gene sequences. Bootstrap values (expressed as percentages of 1000 replications) are given at branch points; only values $>50 \%$ are shown. Arthrobacter globiformis DSM 20124 ${ }^{\top}$ (GenBank accession no. M23411) was used as an outgroup (not shown). Bar, 0.01 substitutions per nucleotide position.

DS- $10^{\mathrm{T}}$ were diphosphatidylglycerol, phosphatidylglycerol and an unidentified glycolipid. The DNA G $+\mathrm{C}$ content of strain DS $-10^{\mathrm{T}}$ was $71.1 \mathrm{~mol} \%$.

Levels of DNA-DNA relatedness between strain DS- $10^{\mathrm{T}}$ and the type strains of four Agromyces species, A. allii, A. salentinus, A. italicus and A. lapidis, its closest phylogenetic neighbours, were in the range $12-40 \%$, indicating that strain DS- $10^{\mathrm{T}}$ represents a genomic species different from these four recognized Agromyces species (Wayne et al., 1987). Strain DS $-10^{\mathrm{T}}$ differed from these species based on several phenotypic characteristics (Table 1). Despite the small phylogenetic divergence between the novel strain and its closest neighbour $(99.3 \%$ 16S rRNA gene sequence similarity), DNA-DNA relatedness data and differential phenotypic properties show that strain DS- $10^{\mathrm{T}}$ can be distinguished from this and all other recognized Agromyces species (Wayne et al., 1987; Stackebrandt \& Goebel, 1994). Therefore, on the basis of the data presented, strain DS- $10^{\mathrm{T}}$ is considered to represent a novel species of the genus Agromyces, for which the name Agromyces terreus sp. nov. is proposed.

\section{Description of Agromyces terreus sp. nov.}

Agromyces terreus (ter're.us. L. masc. adj. terreus of the earth).

Cells are Gram-positive, curved or straight rods, 0.2$0.5 \times 0.7-5.0 \mu \mathrm{m}$. Non-motile. Strict aerobe. Colonies on TSA are circular, convex, smooth, glistening, cream-coloured and $0.8-1.2 \mathrm{~mm}$ in diameter after 3 days incubation at $25{ }^{\circ} \mathrm{C}$. Growth occurs at 10 and $35^{\circ} \mathrm{C}$ with an optimum temperature of $25{ }^{\circ} \mathrm{C}$, but not at 4 or $36{ }^{\circ} \mathrm{C}$. Optimal pH for growth is between 7.0 and 8.0; growth occurs at $\mathrm{pH} 5.0$ and 10.0 , but not at $\mathrm{pH} 4.5$ or 10.5. Growth occurs in the presence of $0-6.0 \%(\mathrm{w} / \mathrm{v}) \mathrm{NaCl}$ with optimum growth in the presence of $0.5-1.0 \%(\mathrm{w} / \mathrm{v}) \mathrm{NaCl}$. Tweens 20, 40 and 60 are hydrolysed. Arginine decarboxylase, lysine decarboxylase, ornithine decarboxylase and tryptophan deaminase are absent. The following substrates are assimilated: glycerol, phenylacetate, D-arabinose, L-arabinose, D-xylose, galactose, glucose, fructose, mannose, rhamnose, $\mathrm{N}$-acetylglucosamine, amygdalin, arbutin, aesculin, salicin, cellobiose, maltose, sucrose, trehalose, inulin, raffinose, starch, glycogen, gentiobiose, turanose and L-fucose. The following substrates are not assimilated: caprate, adipate, erythritol, ribose, L-xylose, adonitol, methyl $\beta$-D-xyloside, sorbose, dulcitol, inositol, mannitol, sorbitol, methyl $\alpha$-D-mannoside, methyl $\alpha$-Dglucoside, lactose, melibiose, melezitose, xylitol, D-lyxose, D-tagatose, D-fucose, D-arabitol, L-arabitol, gluconate, 2ketogluconate and 5-ketogluconate. Acid is produced from aesculin and 5-ketogluconate, but not from erythritol, Lxylose, adonitol, methyl $\beta$-D-xyloside, sorbose, dulcitol, inositol, sorbitol, methyl $\alpha$-D-mannoside, methyl $\alpha$-Dglucoside, melezitose, xylitol, D-lyxose, D-tagatose, D-fucose, D-arabitol, L-arabitol, gluconate or 2-ketogluconate. In assays with the API ZYM system, esterase (C4), esterase lipase (C8), leucine arylamidase, naphthol-AS-BI-phosphohydrolase and $\alpha$-glucosidase are present and acid phosphatase and $\mathrm{N}$-acetyl$\beta$-glucosaminidase are weakly present, but trypsin and $\alpha$ fucosidase are absent. Susceptible to chloramphenicol, cephalothin, gentamicin, tetracycline, carbenicillin, neomycin and oleandomycin, but not to lincomycin. The cellwall peptidoglycan type is B2 $\gamma$, D-Glu-D-Dab. Cell-wall sugars are galactose and ribose. The predominant menaquinones are MK-11, MK-12 and MK-10. Major cellular fatty acids ( $>10 \%$ of total fatty acids) are anteiso- $\mathrm{C}_{15: 0}$, anteiso$\mathrm{C}_{17: 0}$, iso- $\mathrm{C}_{16: 0}$ and iso- $\mathrm{C}_{15: 0}$. Major polar lipids are diphosphatidylglycerol, phosphatidylglycerol and an unidentified glycolipid. The DNA G +C content is $71.1 \mathrm{~mol} \%$.

The type strain, DS- $10^{\mathrm{T}}\left(=\right.$ KCTC $\left.19216^{\mathrm{T}}=\mathrm{JCM} 14581^{\mathrm{T}}\right)$, was isolated from a soil of Dokdo, Korea.

\section{Acknowledgements}

This work was supported by the 21C Frontier Program of Microbial Genomics and Applications (grant MG05-0401-2-0) and the Support and Application Project of Biological Resources (grant M10508050004-06N0805-00410) from the Ministry of Science and Technology (MOST) of the Republic of Korea.

\section{References}

Cowan, S. T. \& Steel, K. J. (1965). Manual for the Identification of Medical Bacteria. London: Cambridge University Press.

Dorofeeva, L. V., Krausova, V. I., Evtushenko, L. I. \& Tiedje, J. M. (2003). Agromyces albus sp. nov., isolated from a plant (Androsace sp.). Int J Syst Evol Microbiol 53, 1435-1438. 
Ezaki, T., Hashimoto, Y. \& Yabuuchi, E. (1989). Fluorometric deoxyribonucleic acid-deoxyribonucleic acid hybridization in microdilution wells as an alternative to membrane filter hybridization in which radioisotopes are used to determine genetic relatedness among bacterial strains. Int J Syst Bacteriol 39, 224-229.

Gledhill, W. E. \& Casida, L. E., Jr (1969). Predominant catalasenegative soil bacteria. III. Agromyces, gen. nov., microorganisms intermediary to Actinomyces and Nocardia. Appl Microbiol 18, 340-349.

Groth, I., Schumann, P., Weiss, N., Martin, K. \& Rainey, F. A. (1996). Agrococcus jenensis gen. nov., sp. nov., a new genus of actinomycetes with diaminobutyric acid in the cell wall. Int J Syst Bacteriol 46, 234 239.

Jung, S.-Y., Lee, S.-Y., Oh, T.-K. \& Yoon, J.-H. (2007). Agromyces allii sp. nov., isolated from the rhizosphere of Allium victorialis var. platyphyllum. Int J Syst Evol Microbiol 57, 588-593.

Jurado, V., Groth, I., Gonzalez, J. M., Laiz, L. \& Saiz-Jimenez, C. (2005a). Agromyces salentinus sp. nov. and Agromyces neolithicus sp. nov. Int J Syst Evol Microbiol 55, 153-157.

Jurado, V., Groth, I., Gonzalez, J. M., Laiz, L., Schuetze, B. \& Saiz-Jimenez, C. (2005b). Agromyces italicus sp. nov., Agromyces humatus sp. nov. and Agromyces lapidis sp. nov., isolated from Roman catacombs. Int J Syst Evol Microbiol 55, 871-875.

Jurado, V., Groth, I., Gonzalez, J. M., Laiz, L. \& Saiz-Jimenez, C. (2005c). Agromyces subbeticus sp. nov., isolated from a cave in southern Spain. Int J Syst Evol Microbiol 55, 1897-1901.

Komagata, K. \& Suzuki, K. (1987). Lipid and cell-wall analysis in bacterial systematics. Methods Microbiol 19, 161-207.

Lányí, B. (1987). Classical and rapid identification methods for medically important bacteria. Methods Microbiol 19, 1-67.

Li, W.-J., Zhang, L.-P., Xu, P., Cui, X.-L., Xu, L.-H., Zhang, Z., Schumann, P., Stackebrandt, E. \& Jiang, C.-L. (2003). Agromyces aurantiacus sp. nov., isolated from a Chinese primeval forest. Int J Syst Evol Microbiol 53, 303-307.

MacKenzie, S. L. (1987). Gas chromatographic analysis of amino acids as the $N$-heptafluorobutyryl isobutyl esters. J Assoc Off Anal Chem 70, 151-160.

Minnikin, D. E., O’Donnell, A. G., Goodfellow, M., Alderson, G., Athalye, M., Schaal, A. \& Parlett, J. H. (1984). An integrated procedure for the extraction of bacterial isoprenoid quinones and polar lipids. J Microbiol Methods 2, 233-241.

Ortiz-Martinez, A., Gonzalez, J. M., Evtushenko, L. I., Jurado, V., Laiz, L., Groth, I. \& Saiz-Jimenez, C. (2004). Reclassification of Agromyces fucosus subsp. hippuratus as Agromyces hippuratus sp. nov., comb. nov. and emended description of Agromyces fucosus. Int J Syst Evol Microbiol 54, 1553-1556.
Rivas, R., Trujillo, M. E., Mateos, P. F., Martínez-Molina, E. \& Velázquez, E. (2004). Agromyces ulmi sp. nov., xylanolytic bacteria from Ulmus nigra in Spain. Int J Syst Evol Microbiol 54, 1987-1990.

Sasser, M. (1990). Identification of bacteria by gas chromatography of cellular fatty acids, MIDI Technical Note 101. Newark, DE: MIDI Inc.

Schleifer, K. H. \& Kandler, O. (1972). Peptidoglycan types of bacterial cell walls and their taxonomic implications. Bacteriol Rev 36, 407-477.

Stackebrandt, E. \& Goebel, B. M. (1994). Taxonomic note: a place for DNA-DNA reassociation and $16 \mathrm{~S}$ rRNA sequence analysis in the present species definition in bacteriology. Int J Syst Bacteriol 44, 846-849.

Suzuki, K., Sasaki, J., Uramoto, M., Nakase, T. \& Komagata, K. (1996). Agromyces mediolanus sp. nov., nom. rev., comb. nov., a species for "Corynebacterium mediolanum" Mamoli 1939 and for some aniline-assimilating bacteria which contain 2,4-diaminobutyric acid in the cell wall peptidoglycan. Int J Syst Bacteriol 46, 88-93.

Takeuchi, M. \& Hatano, K. (2001). Agromyces luteolus sp. nov., Agromyces rhizospherae sp. nov. and Agromyces bracchium sp. nov., from the mangrove rhizosphere. Int J Syst Evol Microbiol 51, 1529-1537.

Tamaoka, J. \& Komagata, K. (1984). Determination of DNA base composition by reversed-phase high-performance liquid chromatography. FEMS Microbiol Lett 25, 125-128.

Wayne, L. G., Brenner, D. J., Colwell, R. R., Grimont, P. A. D., Kandler, O., Krichevsky, M. I., Moore, L. H., Moore, W. E. C., Murray, R. G. E. \& other authors (1987). International Committee on Systematic Bacteriology. Report of the ad hoc committee on reconciliation of approaches to bacterial systematics. Int J Syst Bacteriol 37, 463-464.

Yoon, J.-H., Kim, H., Kim, S.-B., Kim, H.-J., Kim, W. Y., Lee, S. T., Goodfellow, M. \& Park, Y.-H. (1996). Identification of Saccharomonospora strains by the use of genomic DNA fragments and rRNA gene probes. Int J Syst Bacteriol 46, 502-505.

Yoon, J.-H., Lee, S. T. \& Park, Y.-H. (1998). Inter- and intraspecific phylogenetic analysis of the genus Nocardioides and related taxa based on $16 \mathrm{~S}$ rDNA sequences. Int J Syst Bacteriol 48, 187-194.

Yoon, J.-H., Kim, I.-G., Kang, K. H., Oh, T.-K. \& Park, Y.-H. (2003). Alteromonas marina sp. nov., isolated from sea water of the East Sea in Korea. Int J Syst Evol Microbiol 53, 1625-1630.

Zgurskaya, H. I., Evtushenko, L. I., Akimov, V. N., Voyevoda, H. V., Dobrovolskaya, T. G., Lysak, L. V. \& Kalakoutskii, L. V. (1992). Emended description of the genus Agromyces and description of Agromyces cerinus subsp. cerinus sp. nov., subsp. nov., Agromyces cerinus subsp. nitratus sp. nov., subsp. nov., Agromyces fucosus subsp. fucosus sp. nov., subsp. nov., and Agromyces fucosus subsp. hippuratus sp. nov., subsp. nov. Int J Syst Bacteriol 42, 635-641. 